Article

\title{
Investigation on the Chemical and Thermal Behavior of Recycling Agglomerates from EAF by-Products
}

\author{
Thomas Willms ${ }^{1, *(\mathbb{D}}$, Thomas Echterhof ${ }^{1}\left(\mathbb{D}\right.$, Stefan Steinlechner ${ }^{2}\left(\mathbb{D}\right.$, Matti Aula $^{3}$, \\ Ahmed Abdelrahim ${ }^{3} \mathbb{D}$, Timo Fabritius ${ }^{3} \mathbb{D}$, Davide Mombelli ${ }^{4}\left(\mathbb{D}\right.$, Carlo Mapelli ${ }^{4} \mathbb{D}$ and \\ Stefan Preiss 5 \\ 1 Department for Industrial Furnaces and Heat Engineering, RWTH Aachen University, Kopernikusstr. 10, \\ 52074 Aachen, Germany; echterhof@iob.rwth-aachen.de \\ 2 Nonferrous Metallurgy, Montanuniversitaet Leoben, Franz-Josef-Str. 18, 8700 Leoben, Austria; \\ Stefan.Steinlechner@unileoben.ac.at \\ 3 Process Metallurgy Group, University of Oulu, P.O. Box 8000, 90014 Oulu, Finland; \\ matti.aula@oulu.fi (M.A.); Ahmed.AbdelMonem@oulu.fi (A.A.); timo.fabritius@oulu.fi (T.F.) \\ 4 Dipartimento di Meccanica, Politecnico di Milano, Via La Masa 1, 20156 Milano, Italy; \\ davide.mombelli@polimi.it (D.M.); carlo.mapelli@polimi.it (C.M.) \\ 5 MFG Metall-und Ferrolegierungsgesellschaft mbH Hafner, Blondin \& Tidou, Rudolf-Diesel-Str. 9, \\ 40670 Meerbusch, Germany; Stefan.Preiss@mfg-germany.com \\ * Correspondence: willms@iob.rwth-aachen.de
}

Received: 28 October 2020; Accepted: 19 November 2020; Published: 23 November 2020

Featured Application: The aim of this investigation is a simple and easily adaptable agglomeration process for the different quantities and qualities of EAF by-products. The costs and need of disposal for these by-products will be omitted if internal, on-site recycling is possible.

\begin{abstract}
In addition to the blast furnace converter route, electric steel production in the electric arc furnace (EAF) is one of the two main production routes for crude steel. In 2019, the global share of crude steel produced via the electric steel route was $28 \%$, which in numbers is 517 million metric tons of crude steel. The production and processing of steel leads to the output of a variety of by-products, such as dusts, fines, sludges and scales. At the moment, $10-67 \%$ of these by-products are landfilled and not recycled. These by-products contain metal oxides and minerals including iron oxide, zinc oxide, magnesia or alumina. Apart from the wasted valuable materials, the restriction of landfill space and stricter environmental laws are additional motivations to avoid landfill. The aim of the Fines2EAF project, funded by the European Research Fund for Coal and Steel, is to develop a low-cost and flexible solution for the recycling of fines, dusts, slags and scales from electric steel production. During this project, an easy, on-site solution for the agglomeration of fine by-products from steel production has to be developed from lab scale to pilot production for industrial tests in steel plants. The solution is based on the stamp press as the central element of the agglomeration process. The stamp press provides the benefit of being easily adapted to different raw materials and different pressing parameters, such as pressing-force and -speed, or mold geometry. Further benefits are that the stamp press process requires less binding material than the pelletizing process, and that no drying process is required as is the case with the pelletizing process. Before advancing the agglomeration of by-products via stamp press to an industrial scale, different material recipes are produced in lab-scale experiments and the finished agglomerates are tested for their use as secondary raw materials in the EAF. Therefore, the tests focus on the chemical and thermal behavior of the agglomerates. Chemical behavior, volatilization and reduction behavior of the agglomerates were investigated by differential thermogravimetric analysis combined with mass spectroscopy (TGA-MS). In addition, two melts with different agglomerates are carried out in a technical-scale electric arc furnace to increase the sample size.
\end{abstract}


Keywords: electric arc furnace; secondary raw materials; metallurgical by-products; recycling; press agglomeration; stamp press; cement-free briquettes

\section{Introduction}

The agglomeration of residues into briquettes is one way to handle the challenge of reducing the amount of material disposed in landfill and the amount of primary raw materials. Especially during the production of steel by the electric arc furnace (EAF) route different types of by-products occur. These by-products vary in quality and quantity. Some examples are slags, dusts, sludges and scale. The amount of each by-product differs for each plant and ranges from a few $100 \mathrm{t} / \mathrm{y}$ up to over $200,000 \mathrm{t} / \mathrm{y}$. Most of these by-products are not recycled due to a lack of low-cost pre-treatment methods for their recycling. At the moment, they are being disposed in landfill or being used as construction material. Changes in the worldwide environmental policies towards the stricter regulation of applications outside steel plants and restrictions on landfill necessitate integrated pollution prevention and lead to the development of new processes [1-3]. Most of the processes for the recycling of steel production are dedicated to the recovery of metallic oxides like $\mathrm{Zn}$ [4-7]. The most known process for the recycling of EAF dusts is the Waelz process. A rotary kiln is used to recover the zinc from EAF dusts. However, besides the poor quality because of impurities, this is a solution for a single by-product and not internal recycling [5]. Because of their low metal content, the recycling of refractory material for the internal use is a less investigated topic [2]. Due to the high content of $\mathrm{CaO}$ and $\mathrm{MgO}$, refractory material can be used as slag former in the EAF [8,9]. Ladle furnace slag can also be utilized as slag former and substitute primary raw materials such as limestone or dolomite lime. In the theory, the slag could be charged in a liquid state into the EAF, but the coordination of both processes and the handling make it practically impossible. In long-term trials, the possibility of the injection of slag powder was proven [8-12]. Although the agglomeration of EAF by-products via roller press or extrusion press were the aim of many studies, their focus was on by-products with high Cr-content and EAF-dusts [13-18]. However, a simple solution for the internal recycling of the different kinds of EAF-steel plant by-products is still missing.

The aim of the Fines2EAF-Project (funded by the European Research Fund for Coal and Steel) is the on-site agglomeration of by-products of the EAF-steel route. Three European steel plants are participating in the project to find a low-cost and flexible solution to recycle their residues/by-products internally. The stamp press is the central element of the project because it can easily be adapted for different materials and requires a lower amount of binding agent compared to the pelletizing process. Because of the simple technic and the lower content of binder the capital and operational expenditures can be kept low level and contribute to the achievement of economic viability of the process [19]. Furthermore, the adjustable press force, pressing speed and mold size as well as grain size flexibility are specifically beneficial properties of the stamp press for the agglomeration of the different by-products of the steel plants. Another benefit is that the stamp press does not require an additional drying process, as is the case with the pelletizing process $[20,21]$.

This work presents tests to prove the suitability of the agglomerated residues in briquette form for later use in electric arc furnaces as a secondary raw material. The scope is the analysis of the thermal behavior through thermal gravity analysis combined with mass spectrometry. Additional melts in a pilot-scale 45-litre electric arc furnace were carried out to investigate the melting behavior and the metallurgical influence on the steel and slag. An economical and environmental evaluation of the agglomeration process is not part of this work and will be part of a separate work. 


\section{Materials and Methods}

\subsection{Raw Materials}

The residues that are agglomerated in this work are produced during different steps of the electric steel production process chain or sometimes even originate from other manufacturing processes, for instance the grinding sludge is a residue of a local bearing manufacturer located next to the steel plant. Oxy-cutting fines consist of dusty, metallic spheres. Pursuant to its name, these fines originate from cutting billets with an oxygen lance. Belt conveyer fines are fines collected from the belt that supplies lime to the EAF. Combustion chamber dust is a fine material from the dedusting system of the EAF. Ladle furnace slag is a residue of the ladle furnace. Spent refractory is old, worn pieces of furnace lining. Table 1 shows the chemical composition of the residues, their moisture content, bulk density, and true density.

Table 1. Main components and physical properties of the electric arc furnace (EAF) residues.

\begin{tabular}{|c|c|c|c|c|c|c|c|c|c|c|c|c|c|c|c|}
\hline & $\mathrm{Al}_{2} \mathrm{O}_{3}$ & $\mathrm{CaO}$ & $\mathrm{Cr}_{2} \mathrm{O}_{3}$ & $\mathrm{MgO}$ & $\mathrm{MnO}$ & $\mathrm{P}_{2} \mathrm{O}_{5}$ & $\mathrm{~S}$ & $\mathrm{SiO}_{2}$ & $\begin{array}{c}\mathrm{Fe} \\
\text { Total } \\
\text { as } \\
\mathrm{Fe}_{2} \mathrm{O}_{3}\end{array}$ & $\mathrm{Fe}^{2+}$ & $\mathrm{Fe}^{3+}$ & 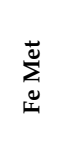 & 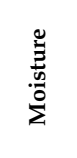 & 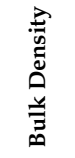 & 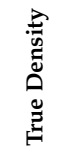 \\
\hline Raw Material & $\begin{array}{l}0 \\
\vdots \\
1 \\
3\end{array}$ & $\begin{array}{l}0 \\
\vdots \\
3 \\
3\end{array}$ & $\begin{array}{l}0 \\
\vdots \\
1 \\
3 \\
3\end{array}$ & $\begin{array}{l}0 \\
\vdots \\
3 \\
3\end{array}$ & $\begin{array}{l}0 \\
\vdots \\
3 \\
3\end{array}$ & $\begin{array}{l}0 \\
\vdots \\
\dot{3} \\
3\end{array}$ & $\begin{array}{l}0 \\
\vdots \\
3 \\
3\end{array}$ & $\begin{array}{l}0 \\
\vdots \\
3 \\
3\end{array}$ & $\begin{array}{l}0 \\
\vdots \\
3 \\
3\end{array}$ & $\begin{array}{l}0 \\
\vdots \\
1 \\
3\end{array}$ & $\begin{array}{l}0 \\
\vdots \\
\vdots \\
\dot{3}\end{array}$ & $\begin{array}{l}0 \\
\vdots \\
\dot{3} \\
\dot{3}\end{array}$ & $0^{\circ}$ & ${ }_{\text {के }}^{n}$ & ${ }_{\text {की }}^{\text {ng }}$ \\
\hline Grinding sludge & 1.069 & 0.157 & 1.739 & 0.102 & 0.320 & 0.437 & 0.085 & 3.577 & 92.09 & 24.1 & 0.3 & 59.2 & 24.787 & 1.192 & 5.302 \\
\hline Belt conveyer fines & 0.214 & 90.08 & 1.064 & 0.995 & 1.452 & 0.337 & 0.211 & 2.979 & 1.759 & - & - & - & - & 1.029 & 3.651 \\
\hline Oxy-cutting fines & 0.170 & 1.295 & 0.654 & 0.368 & 0.815 & 0.530 & 0.188 & 1.065 & 92.72 & 16.4 & 51.5 & 0.3 & 4.73 & 1.824 & 4.739 \\
\hline $\begin{array}{l}\text { Com-bustion } \\
\text { chamber dust }\end{array}$ & 1.911 & 9.301 & 1.289 & 1.950 & 3.455 & 0.631 & 0.199 & 4.389 & 64.09 & 16.4 & 26.9 & 1.8 & 6.397 & 2.193 & 4.276 \\
\hline Ladle Furnace slag & 8.272 & 46.65 & 0.046 & 11.74 & 1.984 & 0.506 & 0.388 & 27.52 & 1.421 & - & - & - & 0.180 & 1.320 & 3.239 \\
\hline Spent refractory & 3.692 & 58.34 & 0.041 & 24.12 & 1.842 & 0.487 & 0.061 & 9.332 & 1.411 & - & - & - & - & 1.805 & 3.867 \\
\hline FeMnC-Dust ${ }^{1}$ & 1.89 & 5.61 & - & 3.38 & 58.81 & 0.06 & - & 9.65 & 2.67 & - & - & - & - & - & - \\
\hline
\end{tabular}

\subsection{Manufacture of Briquettes}

Depending on the material, different processing steps were necessary for processing the residues from electric steel production. Figure 1 shows a flow diagram of the processing steps. In some cases, the materials occur in such a form that no further processing is necessary and the materials can directly be agglomerated. All materials are first screened and coarse and metallic impurities are removed by hand. The target size of the process is a grain size of less than $4 \mathrm{~mm}$. This value was empirically determined in pre-tests and shows good results in this study. Moist materials (moisture $>10 \mathrm{wt}$.- $\%$ ) can be treated by drying. In the industrial processes, this is omitted and the material is processed in the factory to have a lower moisture content. Afterwards, the residual materials are placed on a vibration sieve. Residues larger than $4 \mathrm{~mm}$ are crushed in a jaw crusher and then transferred to a magnetic separator. The magnetic separator is necessary to protect the downstream impact mill. The material is put back onto the vibration sieve and sieved to lump sizes of less than $4 \mathrm{~mm}$. An intensive mixer is used to mix the fine residues, binders and additives. The stamp press is the central element of the agglomeration process and is suitable for the different materials in this project, thanks to its variability with regard to the pressing process and geometry. Through a downstream drying step, it was possible to achieve faster drying of the green compacts during laboratory tests. 


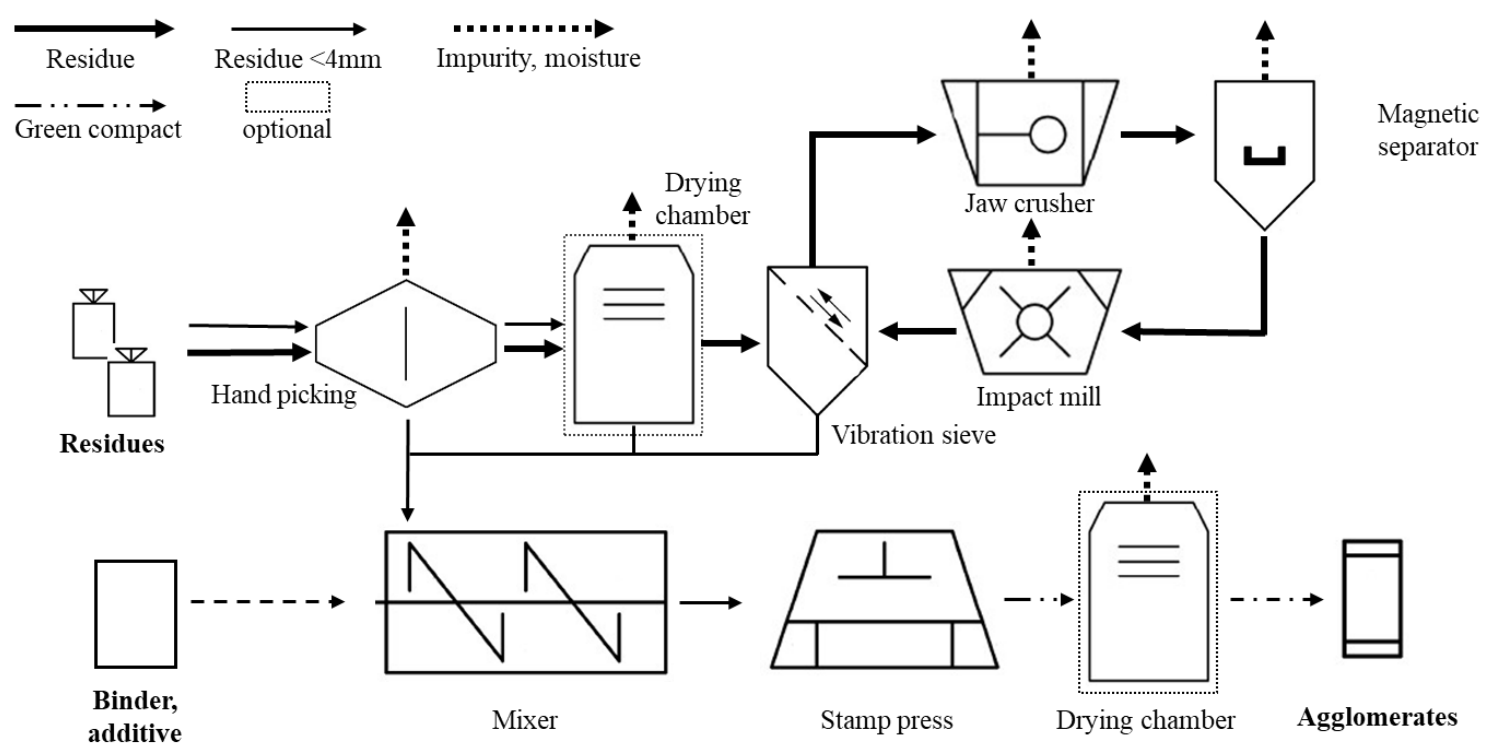

Figure 1. Chart of the manufacturing process.

Several preliminary tests were conducted in which different types of binder, for example, copolymer binders, bitumous binders, polyethylenglycol (PEG), carboxymethylcellulose (CMC), different types of starch and molasses, as well as super absorbers were tested. Furthermore, different agglomeration parameters were tested including pressing force and time, different clearances between the mold and the upper stamp, aging condition and additives such as $\mathrm{CaCO}_{3}$, bentonite, $\mathrm{SiO}_{2}$ and sodium silicate hardener used with sodium silicate binder. Tests with fibers from paper recycling to increase the strength of the briquettes were also done [22].

The results of the pre-tests led to the decision to use starch as binders for the briquettes, and recycled fibers from paper production to increase the strength of the briquettes. Table 2 shows the recipes for the laboratory production of the briquettes.

Table 2. Recipes and preparation.

\begin{tabular}{|c|c|c|c|c|c|c|c|c|c|c|c|c|}
\hline & 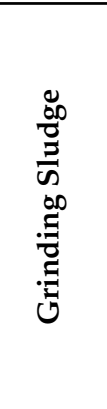 & 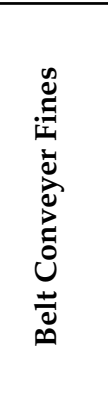 & 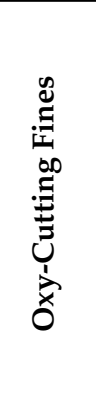 & 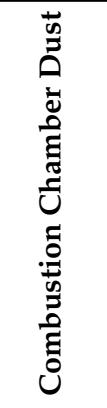 & 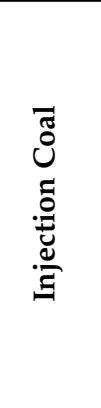 & 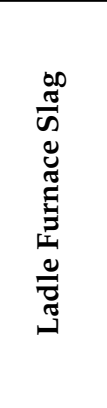 & 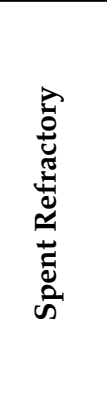 & $\sum_{I I}^{U}$ & $\stackrel{\stackrel{N}{\tilde{J}}}{\stackrel{\sim}{0}}$ & 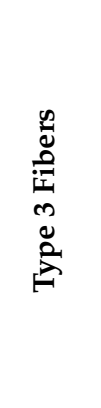 & 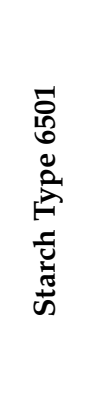 & 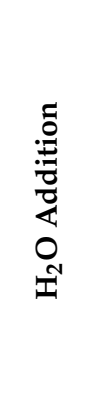 \\
\hline Recipe & wt.-\% & wt.-\% & wt.-\% & wt.-\% & wt.-\% & wt.-\% & wt.-\% & wt.-\% & wt.-\% & wt.-\% & wt.-\% & wt.-\% \\
\hline $\mathrm{CCO} 2$ & - & - & 36.2 & 35.9 & 15.6 & - & - & - & - & 0.9 & 4.0 & 7.4 \\
\hline ВC03 & - & 63.4 & - & - & - & - & - & - & - & 0.7 & 4.8 & 31.1 \\
\hline MA604B & 46.0 & - & 33.8 & - & 10.2 & - & - & - & - & 0.9 & 9.2 & - \\
\hline MH51 & - & - & - & - & - & 55.2 & 27.5 & - & - & 0.8 & 8.3 & 8.3 \\
\hline FD13 & - & - & - & - & 8.4 & - & - & 69.7 & 2.4 & 1.0 & 6.9 & 11.7 \\
\hline
\end{tabular}

Figure 2 shows an example of the manufactured briquettes. The briquettes have a diameter of $73 \mathrm{~mm}$ and a height of 24 to $54 \mathrm{~mm}$ depending on the filling factor of the mold and the manufacturing pressure. 


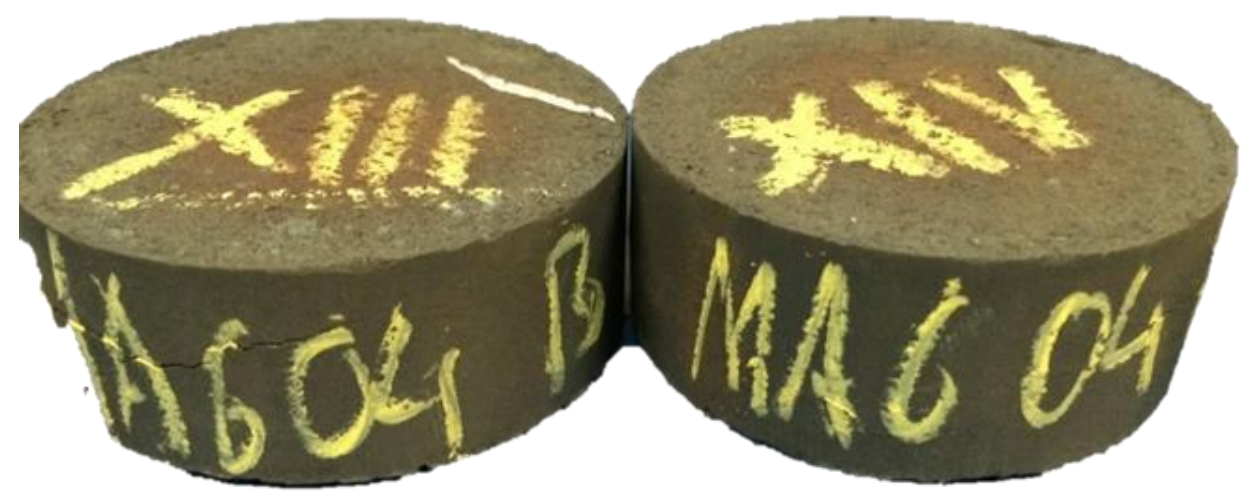

Figure 2. Photograph of the MA604B briquettes manufactured with a $10 \mathrm{~N} / \mathrm{mm}^{2}$ manufacturing pressure.

\subsection{Thermal Behaviour}

Volatizing components, e.g., from reducing agents such as biomass/biochar or lignite fines and/or binder, and the reduction behavior of the briquettes, were determined by differential thermogravimetric analysis combined with mass spectroscopy (TGA-MS) in argon atmosphere at the University of Oulu. TGA-MS tests combined with thermogravimetric experiments give detailed information about the chemical behavior of the briquettes at high temperatures. Some thermogravimetric experiments were carried out in a furnace allowing for a larger sample size, which gives a large enough sample for further analysis about the structure forming in the reduced brick.

The simultaneous thermal analyzer STA 449 F3 Jupiter with graphite furnace coupled with an NETZSCH QMS 403 mass spectrometer was used to analyze the samples and obtain TGA and mass spectroscopy (MS) data.

For all tests, argon gas was introduced to the TGA during the test at a rate of $351.5 \mathrm{~mL} / \mathrm{min}$. This rate was chosen to avoid the oxidation of the evolved gases and/or the tested materials, since similar studies suggest using a high flow rate to minimize such problems [23,24]. The heating rate in the TGA was kept constant at a rate of $5^{\circ} \mathrm{C} / \mathrm{min}$ up to a final temperature of $1600^{\circ} \mathrm{C}$. NETZSCH Proteus ${ }^{\circledR}$ software was used for thermal analysis.

Some of the residues after TGA-MS analysis were characterized through optical and scanning electron microscopy and X-ray diffraction analysis (XRD). The residues being mainly made by iron, they were polished and then etched in Nital 2\% solution ( $98 \%$ ethanol, $2 \%$ nitric acid) to reveal the microstructure. Energy dispersive spectroscopy (EDS) analysis was conducted to analyze locally the chemical composition of the second phases within the iron. XRD analysis was performed by means of a Rigaku SmartLab SE diffractometer, in $\theta-\theta$ Bragg-Brentano configuration, scanning the samples from 5 to $80^{\circ} 2 \theta$ at $0.5^{\circ} / \mathrm{min}$, with a step size of $0.02^{\circ} 2 \theta$ and a fixed divergent slit of $0.5^{\circ}$. To reduce texture effect, the samples was rotated at $120 \mathrm{rpm}$. A copper tube ( $\mathrm{Cu} \mathrm{K \alpha}$ radiation, $\lambda=1.54 \AA$ ) excited at $40 \mathrm{KV}$ and $40 \mathrm{~mA}$ was used to generate X-ray. Diffracted X-ray was collected through 1D D/teX Ultra 250 detector with fluorescence suppressor filter.

\subsection{Pilot-Scale Trials}

The purpose of the trials was to determine the dissolution behavior of agglomerated steel mill residues in an EAF-furnace environment. The trials were carried out using a $50 \mathrm{~kW}$ direct current electric arc furnace (DC-EAF) with a volume of approximately $45 \mathrm{~L}$. The cylindrical vessel can be tilted for casting into prepared molds. A traversable graphite rod-electrode is used, which is anodically connected and immersed into the slag, while the cathode is a graphite bottom electrode. Figure 3 shows the EAF with its transformer. The system is heated via the slag, as it is the component with the highest electric resistance. To start the process, the slag was charged to form a liquid base to which the further feed materials (construction steel alloy) were added. The slag was prepared by remelting a typical slag provided from the partner steel plants. The first trial used $15 \mathrm{~kg}$ of slag provided from 
the first steel mill and $17 \mathrm{~kg}$ steel, whereas the second trial used $10 \mathrm{~kg}$ of slag from the second steel plant and $40 \mathrm{~kg}$ of steel. The agglomerated residues (MH51 $0.9 \mathrm{~kg}$ and MA604B $10 \mathrm{~kg}$ ) were charged and dissolved, and the change in the chemical analysis of the steel and slag phases were determined to evaluate the process performance. The composition of the used briquettes is given in Table 1.

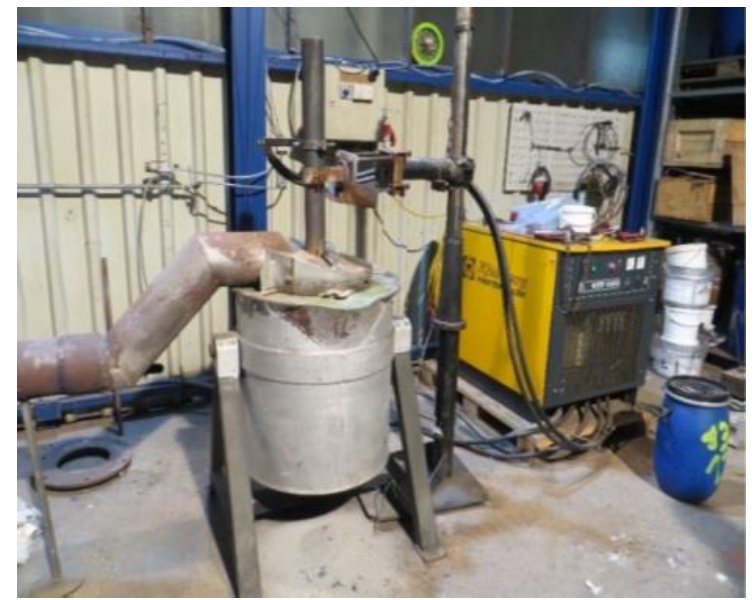

(a)

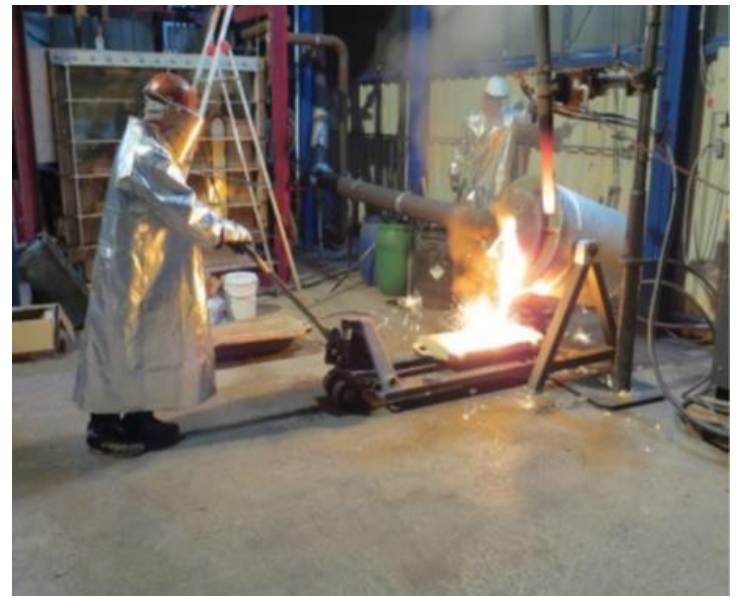

(b)

Figure 3. EAF during operation (a) and tapping (b).

The procedure for both trials was nearly the same. In Table 3, the differences between the two trials are highlighted. After preheating the furnace, the arc was ignited on an initial base of petroleum coke and EAF slag. After the slag was molten, steel scrap was charged into the furnace and melted down. Samples of the steel and slag were taken before the briquettes were charged into the melt. The melt and slag were tapped when the briquettes were completely dissolved and samples of the slag and steel were taken again. The time at which the briquettes were melted was visually determined. The briquettes float on the top of the slag due to their density, which made the determination of dissolution possible just by looking into the furnace.

Table 3. Trial test procedures.

- Overnight heating of the furnace by an electrical pre-heating device up to $400{ }^{\circ} \mathrm{C}$

- Ignition of the arc using petrol coke and charging of $15 \mathrm{~kg}$ of slag to ensure a liquid base in the furnace

- After 25 min: slag entirely liquid, start of stepwise charging of construction steel scrap (17.04 kg)

- $\quad$ After $45 \mathrm{~min}$ the entire feed material was liquid

- Sampling (steel and slag), temperature measurement $\left(1510{ }^{\circ} \mathrm{C}\right)$

- $\quad$ Adding of two briquettes MH51 (each $450 \mathrm{~g}$ )

- After $5 \mathrm{~min}$ the feed briquettes were dissolved entirely

- Sampling (steel and slag), temperature measurement $\left(1585^{\circ} \mathrm{C}\right)$

- $\quad$ Tapping
- Overnight heating of the furnace by an electrical pre-heating device up to $400{ }^{\circ} \mathrm{C}$

- Ignition of the arc using petrol coke and charging of $10 \mathrm{~kg}$ of slag to ensure a liquid base in the furnace

- $\quad$ Slag entirely liquid, start of stepwise charging of construction steel scrap (40 kg), after 165 min the entire feed material was liquid

- Sampling (steel and slag), temperature measurement $\left(1480^{\circ} \mathrm{C}\right)$

- $\quad$ Stepwise adding of briquettes MA604B, due to the carbon content a noteworthy flame formation was objected. The charging of $10 \mathrm{~kg}$ of briquettes took $45 \mathrm{~min}$ after which the material was dissolved entirely

- Sampling (steel and slag), temperature measurement $\left(1530^{\circ} \mathrm{C}\right)$

- $\quad$ Tapping 


\section{Results and Discussion}

\subsection{Thermal Behavior}

Figure 4 shows the diagram of the TGA-MS for the CC02 briquette. Strong ion current signals of $\mathrm{H}_{2} \mathrm{O}+(\mathrm{m} / \mathrm{z}=18)$ evolving starting from a temperature around $100{ }^{\circ} \mathrm{C}$ corresponds to sample moisture evaporation. A strong peak is formed at about $310^{\circ} \mathrm{C}$, which corresponds to binder decomposition. The strong signal persists up to a temperature of $570^{\circ} \mathrm{C}$, indicating chemically bound water leaving the sample. The signal then deteriorates up to a temperature of $670{ }^{\circ} \mathrm{C}$, indicating a small amount of bound water is still leaving the sample. A decrease in mass up to $400^{\circ} \mathrm{C}$ is likely to correspond to water leaving the sample as well as decomposition of fibers and starch. The decomposition fibers and starch is supported by strong peaks corresponding to the release of $\mathrm{CO}$ and $\mathrm{CO}_{2}$ detected at around $288^{\circ} \mathrm{C}$. A decrease in mass starting around 700 and $950{ }^{\circ} \mathrm{C}$ likely corresponds to the reduction of hematite and magnetite, respectively. $\mathrm{CO}_{2}$ is also detected at $763{ }^{\circ} \mathrm{C}$, suggesting that significant reduction by $\mathrm{CO}$ is taking place, probably due to the iron oxides present in the briquette sample. A significant $\mathrm{CO}$ peak is detected near the end of measurement at around $1575^{\circ} \mathrm{C}$, suggesting that further reduction of oxides is taking place.

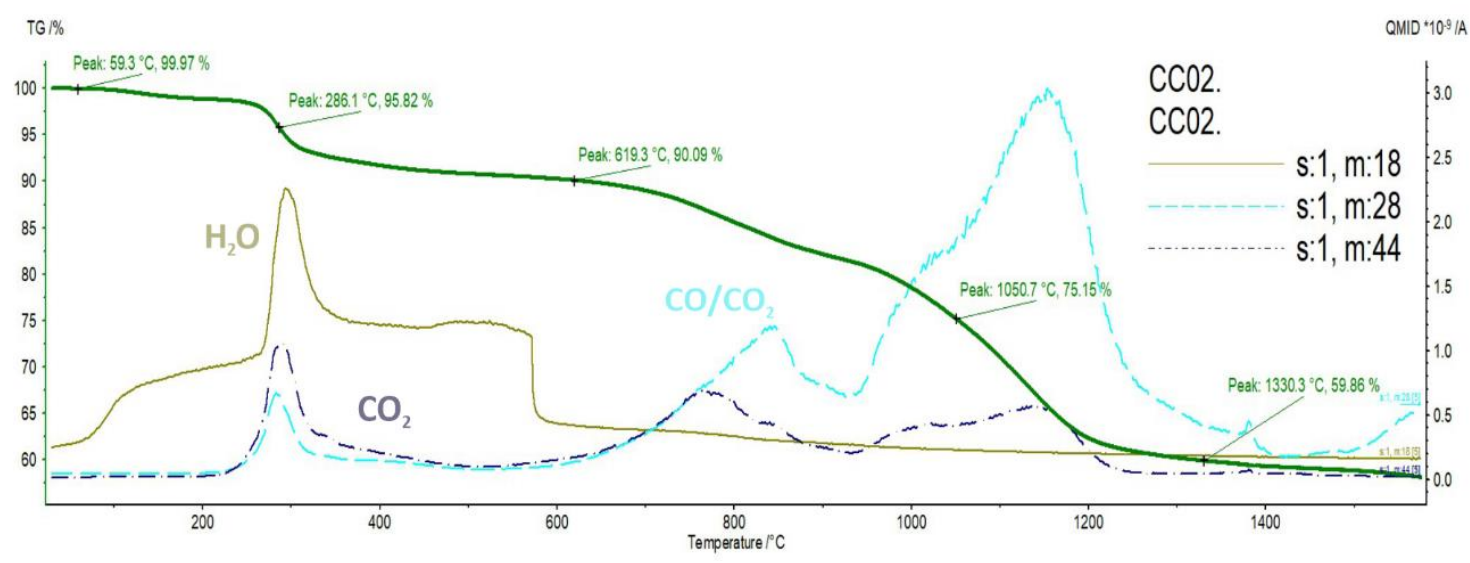

Figure 4. CC02 thermogravimetric analysis combined with mass spectroscopy (TGA-MS) diagram.

The results deduced from the MS analysis are confirmed by optical microscopy and XRD analysis of briquette residues collected from the crucible. Most of the briquette converted into metallic material, the microstructure and chemical composition of which are reported in Figures 5 and 6 and Table 4 . The iron has assumed a typical cast-iron microstructure, with a pearlitic matrix surrounded by primary cementite and graphite flakes.

The non-metallic residue is mainly formed by unreduced iron oxides (especially wustite). An intense and wide XRD peak associated to unburned carbon is detected (Figure 7). Akermanite is due to the reaction between oxides within the bricks and TGA crucible.

The BC03 briquette mainly consists of conveyer belt fines (more than $63 \mathrm{wt} .-\%$ ). The chemical analysis of conveyer belt fines shows that consists of more than 90 wt.- $\% \mathrm{CaO}$, which is very stable at high temperatures and cannot be reduced by carbon at the testing temperature range according to the Ellingham diagram. Moreover, water addition during the making of the briquette was $31.1 \%$. 

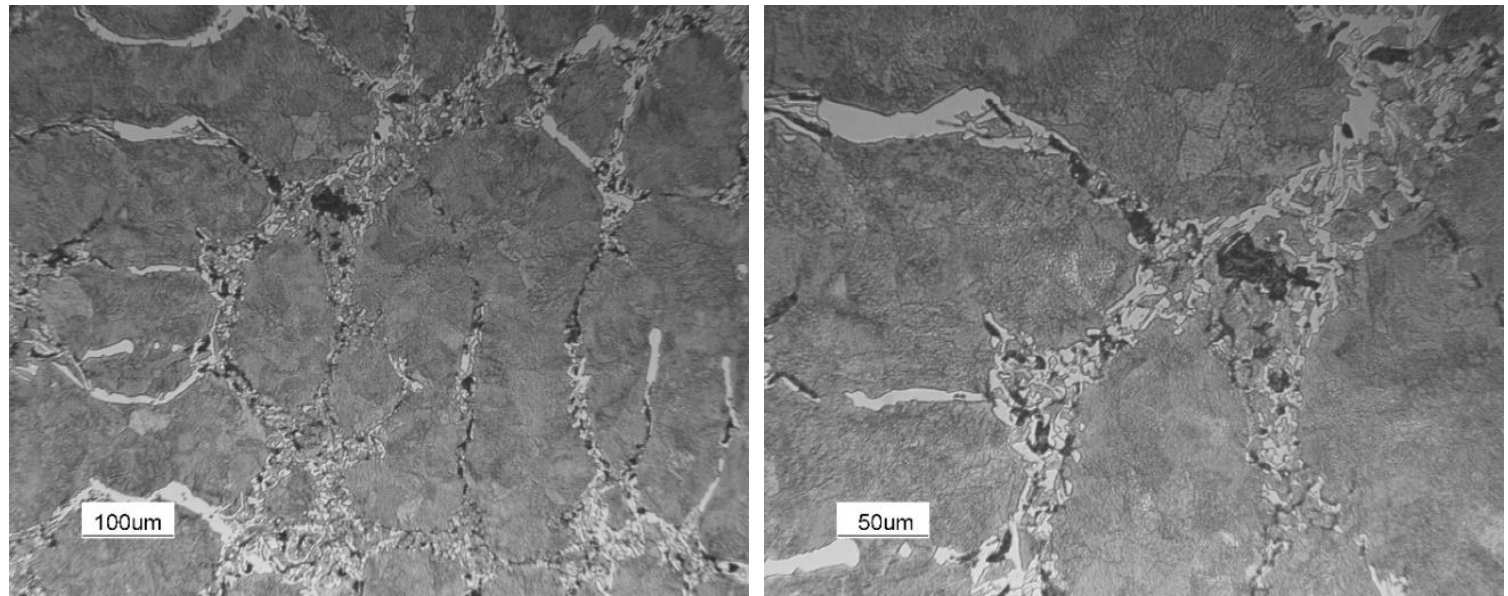

Figure 5. Optical microscope microstructure of metallic material obtained after CC02 dilatometer test (Nital 2\%).

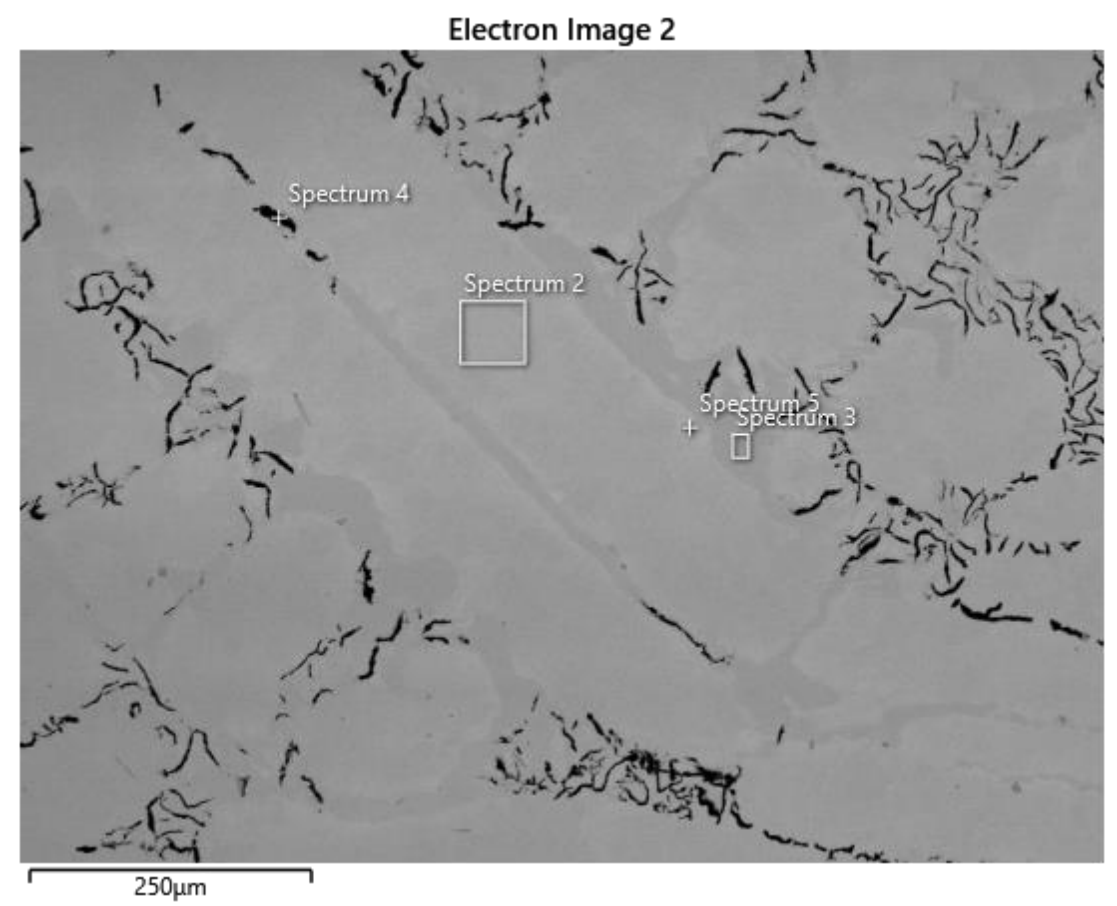

Figure 6. SEM-energy dispersive spectroscopy (EDS) local chemical composition of metallic material obtained after $\mathrm{CC} 02$ dilatometer test.

Table 4. SEM-EDS chemical composition of obtained metallic material after CC02 dilatometer test (\% by weight).

\begin{tabular}{ccccccccccc}
\hline wt.-\% & $\mathbf{C}$ & $\mathbf{F}$ & $\mathbf{A l}$ & $\mathbf{S i}$ & $\mathbf{S}$ & $\mathbf{P}$ & $\mathbf{C r}$ & $\mathbf{V}$ & $\mathbf{M n}$ & $\mathbf{F e}$ \\
\hline $\begin{array}{c}\text { General } \\
\text { chemical }\end{array}$ & 6.2 & - & 0.2 & 0.2 & 0.1 & - & 0.8 & - & 0.6 & 92 \\
composition & & & & & & & & & & \\
Spectrum 2 & 3.0 & - & 0.2 & 0.2 & - & - & 0.5 & - & 0.5 & 95.7 \\
Spectrum 3 & 5.1 & 1.3 & 0.1 & - & 0.2 & - & 2.9 & 0.1 & 0.7 & 89.6 \\
Spectrum 4 & 40.5 & - & 0.1 & 0.1 & - & - & 0.5 & - & - & 58.8 \\
Spectrum 5 & 4.1 & & 0.2 & 0.2 & 0.2 & 0.2 & 0.7 & - & 0.7 & 93.7 \\
\hline
\end{tabular}

Figure 8 shows the TGA-MS diagram of BC03. During the initial stage of the heat, water and volatiles appear to be leaving the sample. The first sharp drop in the sample mass starting from 
around $400{ }^{\circ} \mathrm{C}$ is probably due to the release of chemically bound water. The $\mathrm{CO}$ and $\mathrm{CO}_{2}$ peaks at around $250{ }^{\circ} \mathrm{C}$ probably correspond to the decomposition of starch and fibers. The second sharp decrease in mass occurring from 600 to $800^{\circ} \mathrm{C}$ is likely due to the decomposition of residual calcium carbonate, as the loss of mass corresponds to significant peaks in $\mathrm{CO}$ and $\mathrm{CO}_{2}$. For instance, at $1 \mathrm{~atm}$ pressure, $\mathrm{CaCO}_{3}$ decomposes in the range $900-1200^{\circ} \mathrm{C}$. However, under argon flow, calcium carbonate decomposes to a lower temperature, typically in the range $550-950{ }^{\circ} \mathrm{C}$ [25] Another source indicates the decomposition peak at $750{ }^{\circ} \mathrm{C}$ [26], whereas Drobikova et al. [27] indicate that $\mathrm{CaCO}_{3}$ decomposes in the temperature range between 570 and $830{ }^{\circ} \mathrm{C}$. Thus, the $\mathrm{CO}_{2}$ peak is certainly associated to calcite decomposition.

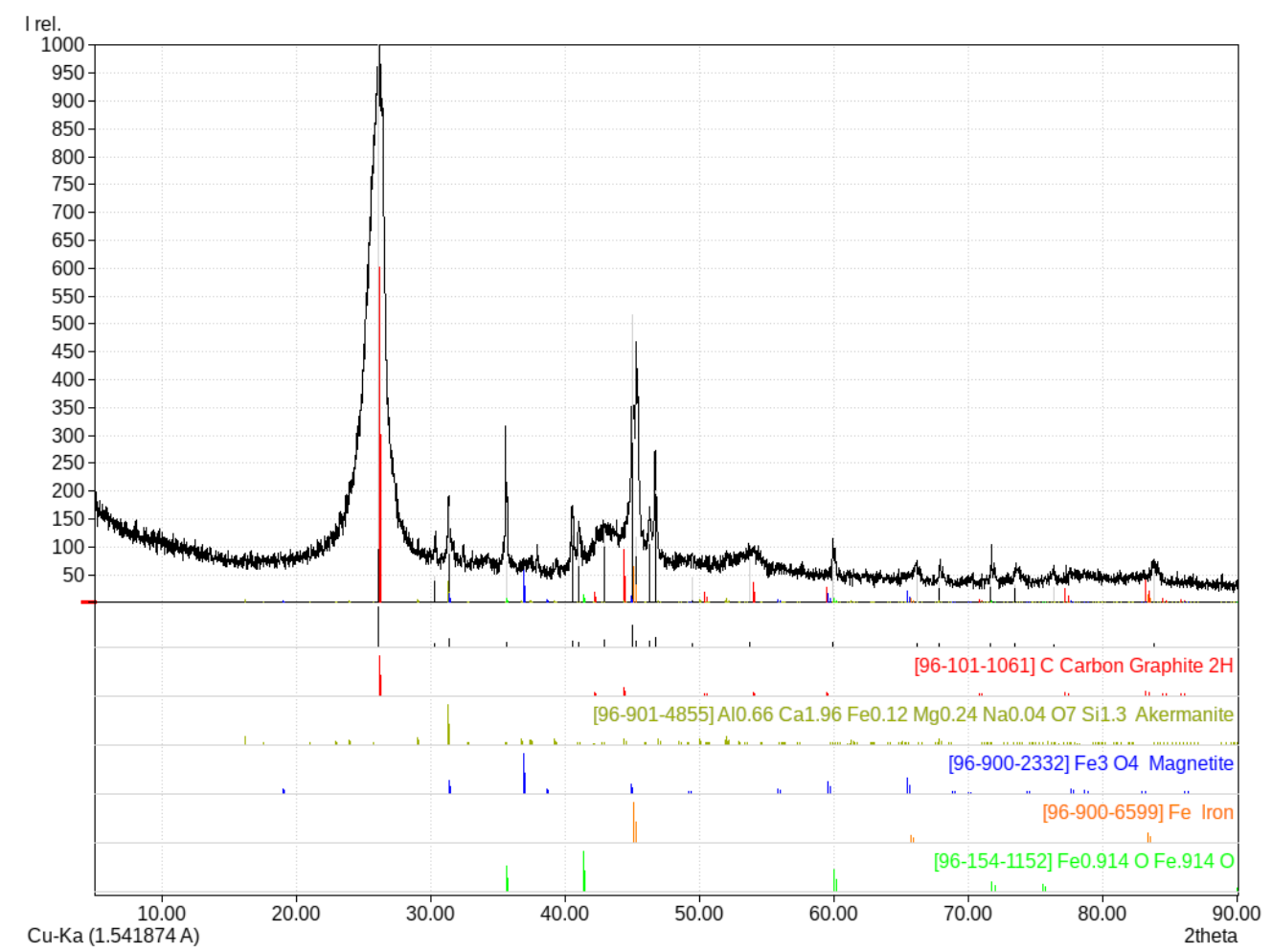

Figure 7. X-ray diffraction (XRD) pattern of CC02 briquette after TGA-MS test.

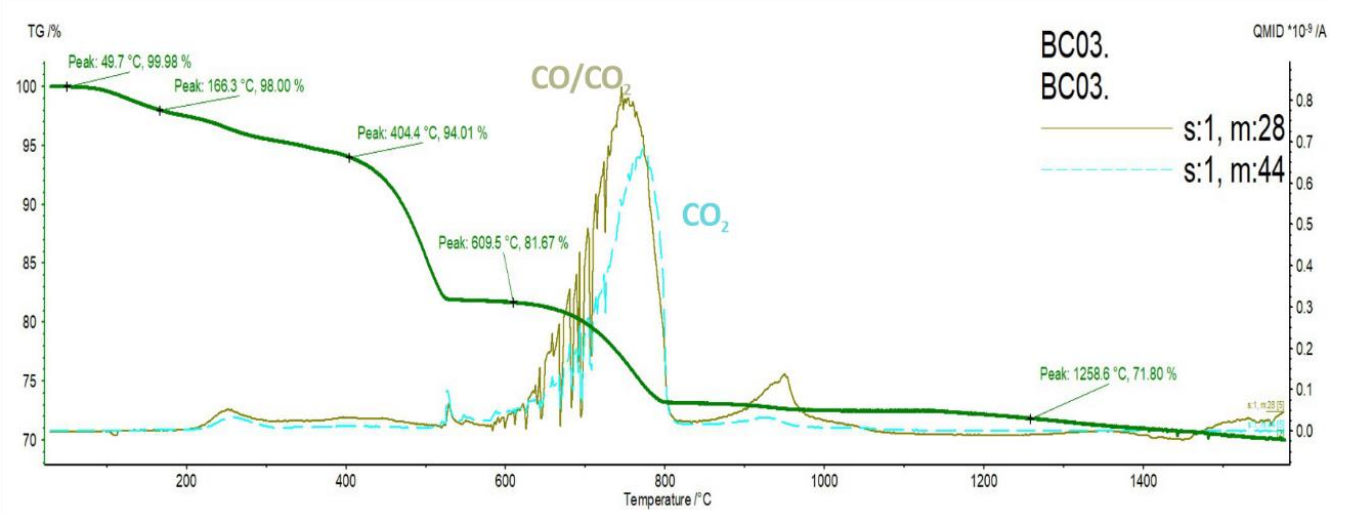

Figure 8. BC03 TGA-MS diagram.

The FD13 briquette consists mainly of FMC (69.7 wt.-\%). It also has a significant amount of added water (11.7 wt.-\%). Figure 9 shows a diagram of the TGA-MS analysis. Water appears to be released from the sample at a temperature of between 100 and $535^{\circ} \mathrm{C}$. At around $250^{\circ} \mathrm{C}$, a small amount of mass is lost, probably due to the decomposition of starch and fibers. This is consistent with the small CO and 
$\mathrm{CO}_{2}$ peak. $\mathrm{CO}_{2}$ also peaks significantly near $533^{\circ} \mathrm{C}$, indicating that reduction takes place. Two more significant $\mathrm{CO}$ and $\mathrm{CO}_{2}$ peaks appear near $680^{\circ} \mathrm{C}$ accompanied by a steep and short decreasing mass curve, likely indicating another reduction. From 1200 to $1600{ }^{\circ} \mathrm{C}$, the briquette lost more than $20 \%$ of its total original mass accompanied by a release of $\mathrm{CO}$, indicating that high temperature reduction took place during this stage.

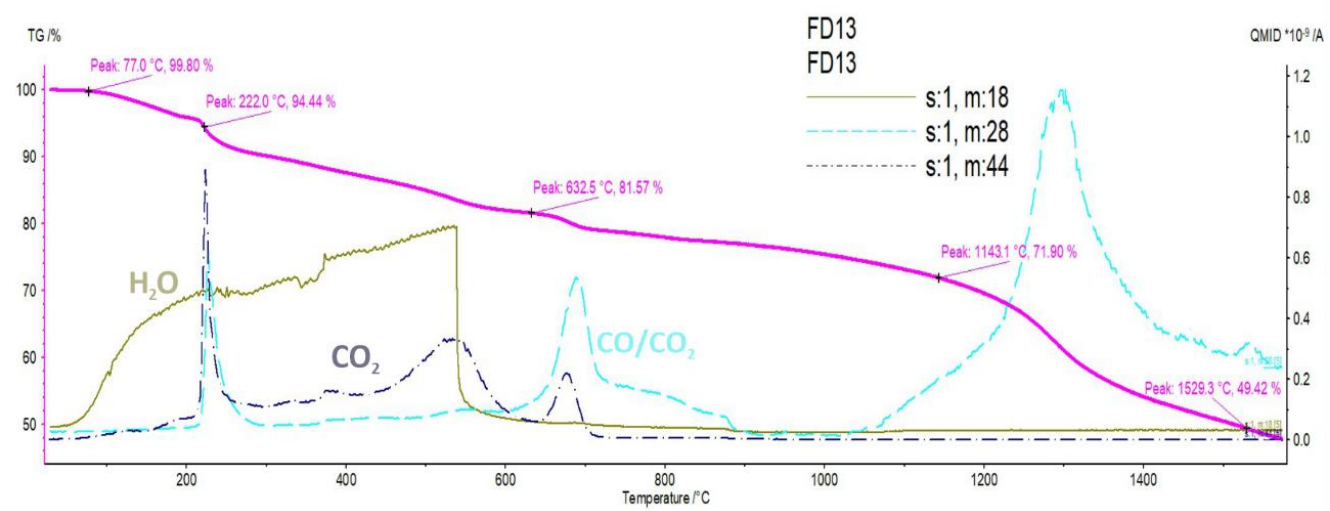

Figure 9. FD13 TGA-MS diagram.

The analysis of the residue collected from the TGA crucible shows that a small fraction of metallic manganese was obtained by the reduction of manganese oxide (Figure 10). However, the main product after the thermal test was manganese silicide carbide ( $\mathrm{Mn} 5 \mathrm{SiC})$. This is a typical product of carbothermic reduction of manganese ores, as stated by Kononov [28]. A residual fraction of hausmannite $\left(\mathrm{Mn}_{3} \mathrm{O}_{4}\right)$ and $\mathrm{Mn}_{2} \mathrm{O}_{3}$ bearing compound (potassium birnessite) was observed.

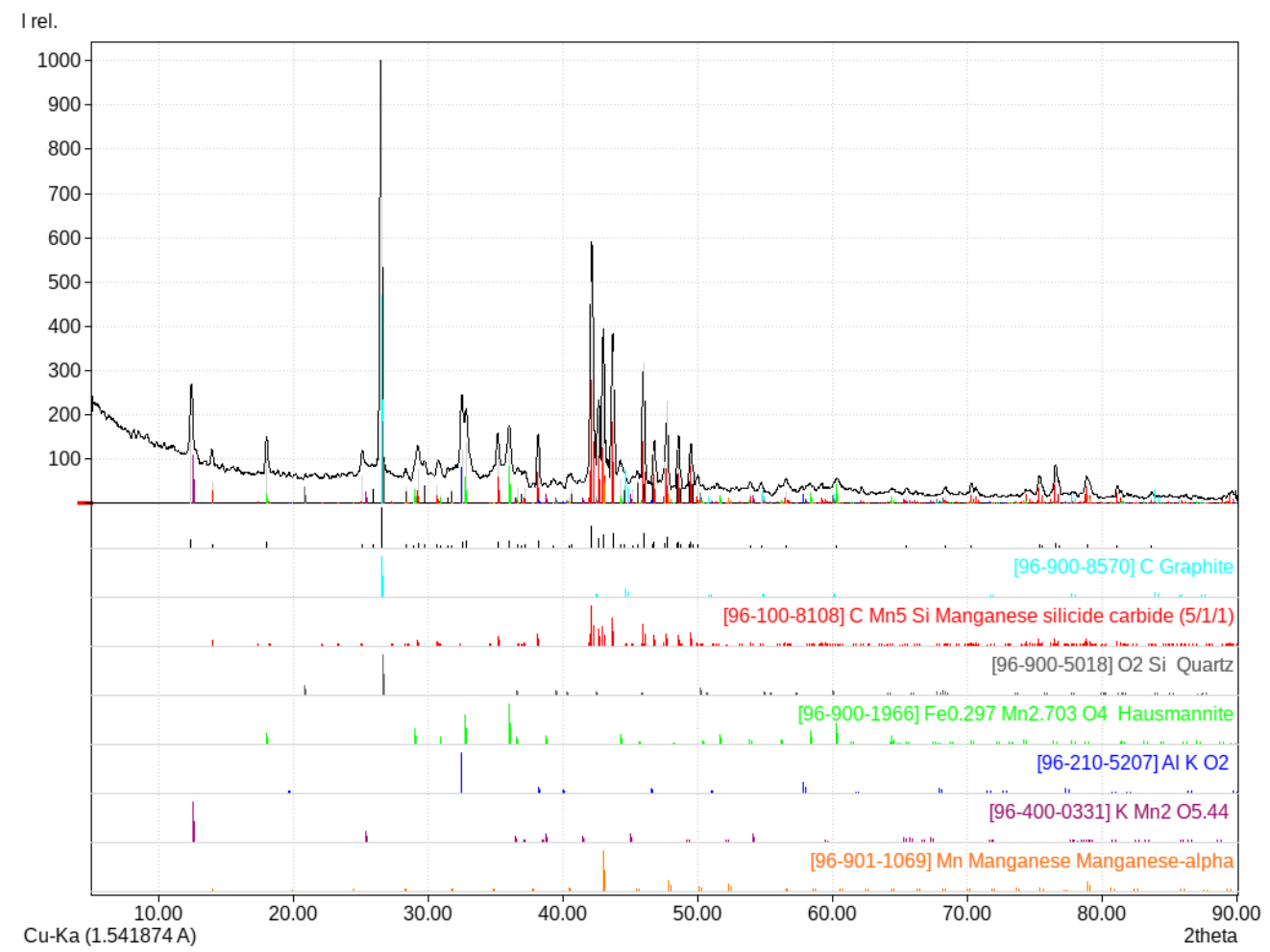

Figure 10. XRD pattern of FD13 briquette after TGA-MS test.

Figure 11 shows the TG-MS diagram of MA604B. MA604B mainly comprises grinding sludge and oxy-cutting fines. Grinding sludge and oxy-cutting fines consist for the most part of iron and iron 
oxides. In addition to grinding sludge and oxy-cutting fines, the briquette contains injection carbon which is mostly carbon. Water appears to be leaving the sample just under $100{ }^{\circ} \mathrm{C}$ up to $400{ }^{\circ} \mathrm{C}$. Again, a small mass change near $250^{\circ} \mathrm{C}$ accompanied with $\mathrm{CO}$ and $\mathrm{CO}_{2}$ peaks suggest that fibers and starch are decomposed. Starting from a temperature of around $700{ }^{\circ} \mathrm{C}$, it can be seen that there is continuous mass loss accompanied by emission of $\mathrm{CO}$ and $\mathrm{CO}_{2}$. This indicates that carbon is utilized to reduce iron oxides in the following order Hematite $\rightarrow$ Magnetite $\rightarrow$ Wuestite $\rightarrow$ Metallic iron. Around $1100{ }^{\circ} \mathrm{C}$, the mass loss becomes steeper, suggesting that further iron oxide reduction takes place.

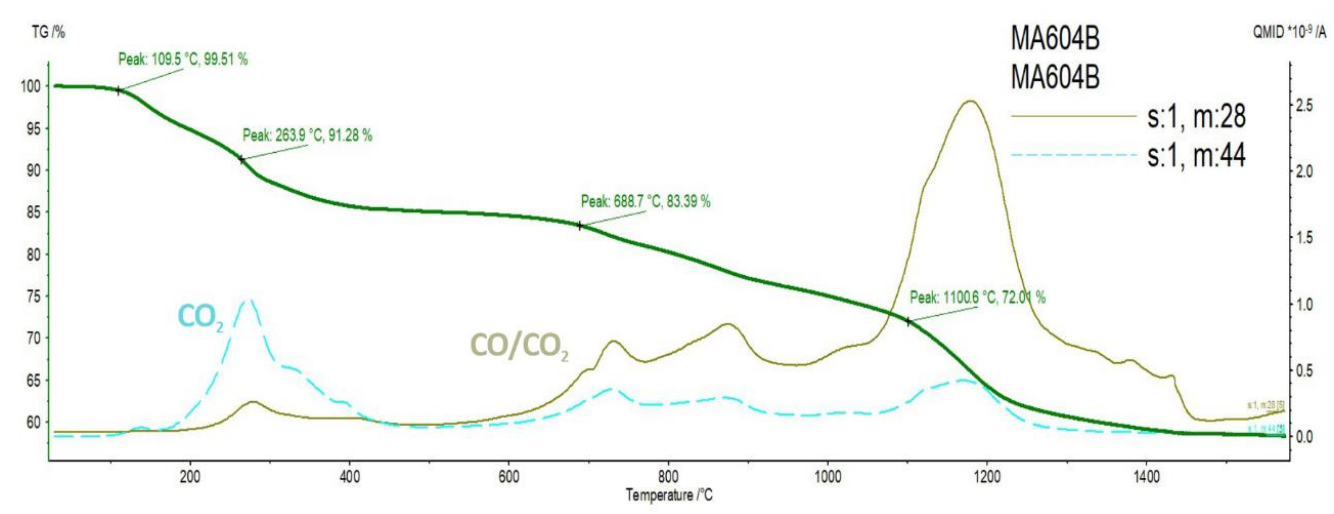

Figure 11. MA604B TGA-MS diagram.

A summary of TGA-MS results is presented in Table 5.

Table 5. Summary of TGA-MS results.

\begin{tabular}{|c|c|c|c|c|}
\hline Sample & Reaction 1 & Reaction 2 & Reaction 3 & Reaction 4 \\
\hline $\mathrm{CC} 02$ & $\begin{array}{l}\text { Binder decomposition } \\
\text { at } 286^{\circ} \mathrm{C} \text {, fast }\end{array}$ & Reduction at $800-1400^{\circ} \mathrm{C}$ & & \\
\hline $\mathrm{BC} 03$ & $\begin{array}{l}\text { Binder decomposition } \\
200-500{ }^{\circ} \mathrm{C} \text {, slow }\end{array}$ & $\begin{array}{c}\mathrm{CaCO}_{3} \text { decomposition } \\
\text { at } 600-800^{\circ} \mathrm{C}\end{array}$ & & \\
\hline FD13 & $\begin{array}{l}\text { Binder decomposition } \\
\text { at } 222^{\circ} \mathrm{C} \text {, fast }\end{array}$ & $\begin{array}{l}\text { Slow water removal } \\
\text { at } 100-500{ }^{\circ} \mathrm{C}\end{array}$ & $\begin{array}{c}\text { Decomposition of } \\
\text { manganese ore at } 6700^{\circ} \mathrm{C}\end{array}$ & $\begin{array}{l}\text { Reduction at } \\
1100-1500{ }^{\circ} \mathrm{C}\end{array}$ \\
\hline MA604B & $\begin{array}{l}\text { Evaporation of free } \\
\text { water at } 109-200{ }^{\circ} \mathrm{C}\end{array}$ & $\begin{array}{l}\text { Slow decomposition of } \\
\text { binder at } 200-400^{\circ} \mathrm{C}\end{array}$ & $\begin{array}{l}\text { Slow reduction at } \\
700-1100^{\circ} \mathrm{C}\end{array}$ & $\begin{array}{l}\text { Fast reduction at } \\
1100-1250^{\circ} \mathrm{C}\end{array}$ \\
\hline
\end{tabular}

\subsection{Pilot-Scale Trials}

For the trial with briquettes from MA604B, a total of $48.0 \mathrm{~kg}$ of iron alloy was tapped. The $8.0 \mathrm{~kg}$ mass increase in the alloy can be explained by both the reduction of iron oxide from the slag and the dissolution of the briquettes, which consist mainly of iron. It was not possible to determine the exact slag mass as significant amounts solidified in the furnace vessel during the tapping procedure. As shown in Table 6, the chemical analysis of the ferrous alloy was not significantly influenced by the charging of the briquettes. The carbon content of the steel sample is high because of the dissolution of carbon from the bottom and top electrodes in the furnace. The chemical composition of the slag phase shows a drop in basicity due to the charging of the briquettes. At the same time, the iron oxide content decreased as can be seen in Table $7 . \mathrm{MgO}$ on the other hand increased slightly. The experiment showed a good dissolution behavior of the briquettes although the ratio of charged material compared to the pre-molten slag and iron alloy was probably higher than it will be in an industrial application. Additionally, the iron content of the slag decreased, indicating good separation of the contained metallic iron without any unwanted oxidation. However, partial reduction of iron oxide by the electrode cannot be neglected.

For the trial with briquettes from MH51, a total of $19.6 \mathrm{~kg}$ ferrous alloy was tapped. The mass increase was due to the partial reduction of iron oxide from the slag and the dissolution of the charged briquettes. It was not possible to determine the exact slag mass as significant amounts solidified in the 
furnace vessel during the tapping procedure. Comparing the chemical analysis of the steel and slag phase before and after the adding of the briquettes in Tables 5 and 6, it is evident that the composition was not influenced significantly. The high carbon content is due to the slight dissolution of the bottom and top electrode. The objective of the experiment was to evaluate the dissolving behavior of the briquettes in the slag when utilizing $\mathrm{CaO}$ as a substitute, and its influence on the chemical composition of slag and metal phase. The dissolution took place rapidly. The mass of charged briquettes was low compared to the amount of pre-molten slag and did not change the steel composition significantly. The target of substituting $\mathrm{CaO}$ additives with the briquettes seems to be achievable based on the good dissolution behavior.

Table 6. Composition of the steel before and after adding the briquettes.

\begin{tabular}{ccccccccccccccc}
\hline Recipe & in wt.-\% & Fe & C & Si & Mn & P & S & Cr & Ni & Mo & Cu & V & Sn & N \\
\hline \multirow{2}{*}{ MH51 } & Steel sample before & 95.3 & $>1.68$ & 0.04 & 1.21 & 0.12 & 0.02 & 0.98 & 0.13 & 0.03 & 0.34 & 0.02 & 0.02 & 0.006 \\
& Steel sample after & 95.1 & $>1.68$ & 0.03 & 1.39 & 0.13 & 0.02 & 0.95 & 0.14 & 0.03 & 0.35 & 0.02 & 0.02 & 0.009 \\
\hline \multirow{2}{*}{ MA604B } & Steel sample before & 94.17 & $>1.68$ & 0.004 & 1.18 & 0.06 & 0.02 & 0.4 & 0.09 & 0.02 & 0.17 & 0.02 & 0.02 & 0.02 \\
& Steel sample after & 93.62 & $>1.68$ & 0.002 & 1.11 & 0.07 & 0.03 & 0.54 & 0.109 & 0.03 & 0.2 & 0.02 & 0.02 & 0.02 \\
\hline
\end{tabular}

Table 7. Composition of the slag before and after adding the briquettes.

\begin{tabular}{lcccccccccc}
\hline Recipe & in wt.- $\%$ & $\mathbf{C a O}$ & $\mathbf{S i O}_{2}$ & $\mathbf{M g O}$ & $\mathbf{A l}_{\mathbf{2}} \mathbf{O}_{3}$ & $\mathbf{M n O}$ & $\mathbf{F e}_{\mathbf{2}} \mathbf{O}_{3}$ & $\mathbf{C r}_{2} \mathbf{O}_{3}$ & $\mathbf{T i O}_{2}$ & $\mathbf{S}$ \\
\hline \multirow{2}{*}{ MH51 } & Slag sample before & 42.5 & 16.4 & 5.7 & 7.2 & 3.7 & 11.6 & 0.5 & 0.8 & 0.23 \\
& Slag sample after & 40.1 & 19.2 & 9.9 & 7.1 & 3.2 & 5.2 & 0.2 & 0.7 & 0.15 \\
\hline \multirow{2}{*}{ MA604B } & Slag sample before & 40.6 & 18.2 & 8.0 & 13.4 & 4.4 & 3.5 & 0.4 & 0.8 & 0.54 \\
& Slag sample after & 39.9 & 17.6 & 7.8 & 11.7 & 3.7 & 3.0 & 0.4 & 0.7 & 0.23 \\
\hline
\end{tabular}

\section{Conclusions}

The results show that the production of briquettes from metallurgical residues with the stamp press is feasible. Furthermore, these briquettes have sufficient physical properties, i.e., good abrasion resistance and compression strength over $25 \mathrm{MPa}$. The combination of different residues leads to briquettes that include only secondary raw materials, binders and fibers.

The thermal behavior of the investigated briquettes shows that a reduction of iron could take place during the heating of the briquettes and no abrupt release of gases takes place that could destroy the briquettes.

The pilot trials were a success because the briquettes influenced the steel and slag as expected. The mass of iron increased in the test with MA604B briquettes, thus indicating that an unwanted oxidation of the carbon had not taken place and the carbon reduced the iron oxides. The dissolving behavior of the lime-rich briquettes was good; a substitution of primary lime or limestone in the EAF-process could be possible.

The next step will focus on the industrial scale-up. This will include the production of $100 \mathrm{t}$ of briquettes in total for industrial tests. These tests will be performed at steelmaking plants in three different types of electric arc furnaces.

Author Contributions: Conceptualization, T.W., M.A., D.M. and S.S.; validation, T.E. and M.A.; investigation, T.W., S.P., M.A., S.S. and A.A.; writing—original draft preparation, T.W., T.E., M.A. and S.S.; writing-review and editing, T.W., M.A., D.M. and S.P.; visualization, T.W., S.S., M.A., D.M. and S.P.; supervision, T.E., C.M. and T.F. All authors have read and agreed to the published version of the manuscript.

Funding: This project has received funding by the European Commission from the Research Fund for Coal and Steel under grant agreement No 754197. This paper reflects only the author's view and the Commission is not responsible for any use that may be made of the information it contains.

Conflicts of Interest: The authors declare no conflict of interest. The funders had no role in the design of the study; in the collection, analyses, or interpretation of data; in the writing of the manuscript, or in the decision to publish the results. 


\section{References}

1. Algermissen, D.; Morillon, A.; Wendler, B.; Kozariszczuk, M.; Cirilli, F.; Miceli, P. Control of Slag Quality for Utilisation in the Construction Industry (SLACON): Final Report; Publications Office of the European Union: Luxembourg, 2017; Volume 28460.

2. Stubbe, G.; Harp, G.; Marx, K.; Ebner, M.; Mirabile, D.; Pistelli, M.I. Upgrading and Utilisation of Residual Iron Oxide Materials for Hot Metal Production (URIOM): Final Report; Publications Office of the European Union: Luxembourg, 2013; Volume 25081.

3. Derungs, P.; Brouhon, J.M.; Harp, G. Briquetting of Self-Reducing Blendings of Waste Iron Oxide Mixtures: Final Report; Publications Office of the European Union: Luxembourg, 2002; Volume 2018.

4. Wozniacki, Z.; Telejko, T.K. Sintering as the method of utilization of steelmaking dusts with a high content of zinc oxides. Hutnik-WH 2014, 81, 166-171.

5. Stevart, C. Sustainability in Action: Recovery of Zinc from EAF Dust in the Steel Industry, 2015. Intergalva Conference, Liverpool, England, June 2015. Available online: http:/www.icz.org.br/upfiles/ arquivos/apresentacoes/intergalva-2015/5-2-Stewart.pdf (accessed on 24 April 2018).

6. Palimaka, P.; Pietrzyk, S.; Stepien, M. Recycling of Zinc from the Steelmaking Dust in the Sintering Process. In Energy Technology 2017, The Minerals, Metals E Materials Series; Zhang, L., Drelich, J.W., Neelameggham, N.R., Eds.; Springer: Cham, Switzerland, 2017; pp. 181-189. ISBN 978-3-319-52191-6.

7. Palimąka, P.; Pietrzyk, S.; Stępień, M.; Ciećko, K.; Nejman, I. Zinc Recovery from Steelmaking Dust by Hydrometallurgical Methods. Metals 2018, 8, 547. [CrossRef]

8. Kuehn, M.; Cores, A.; Drissen, P.; Kuehn, M.; Jung, H.; Mernitz, J.; Richter, F.; Veneri, N. Efficient Utilisation of Raw Materials used in Secondary Metallurgy as Flux in Steelmaking Furnaces; ECSC research project $\mathrm{N}^{\circ}$ 7210-PR-203, Final Report; Publications Office of the European Union Luxembourg 2985: Luxembourg, 2005.

9. Porisiensi, S. Recycling of Ladle Slag and Spent Refractories by Injection Into an EAF. Iron Steel Technol. 2004, 1, 63-66.

10. Memoli, F.F.; Memoli, F.; Brioni, O.; Mapelli, C.; Guzzon, M.; Sonetti, O. Recycling of Ladle Slag in the EAF: A Way to Improve Environmental Conditions and Reduce Variable Costs in the Steel Plants-The results of Stefana SpA (Italy). In Iron \& Steel Technology Conference Proceedings (AISTech); Association for Iron and Steel Technology: Warrendale, PA, USA, 2006; Volume II, pp. 1171-1179.

11. Sahajwalla, V.; Guzzon, M.; Mapelli, C.; Sahajwalla, V.; Saha-Chaudhury, N.; Memoli, F.; Pustorino, M. Recycling Ladle Slag as Slag Former for EAF Steelmaking-A Study of Foaming Behavior. In Iron E Steel Technology Conference Proceedings (AISTech); Association for Iron and Steel Technology: Warrendale, PA, USA, 2007; Volume I, pp. 1-10.

12. Schliephake, H. Sustainable stabilisation and reuse of ladle furnace slag from electric steelmaking. In Proceedings of the 7th European Slag Conference Proceedings, Aachen, Germany, 9-11 October 2013; pp. 47-59.

13. TMS; Grillo, F.F.; De Oliveira, P.J.R.; Espinosa, D.C.; Tenorio, P.J.A.S. Addition of Electric Arc Furnace Dusts in Hot Metal; Wiley: Hoboken, NJ, USA, 2012; pp. 361-367.

14. Yang, Q.; Holmberg, N.; Björkman, B. EAF smelting trials of briquettes at Avesta Works of Outokumpu Stainless AB for recycling oily mill scale sludge from stainless steel production. In Proceedings of the International Conference on Process Development in Iron and Steelmaking, Luleå, Sweden, 8-11 June 2008; pp. 561-570.

15. Aalto, P.; Johansson, M. In-Plant Recycling of Dust and Sludge: Experience from the Oxyfines Concept. In Proceedings of the SCANMET II: 2nd International Conference on Process Development in Iron and Steelmaking, Lulea, Sweden, 6-9 June 2004; pp. 481-490.

16. Akhmetov, A.B.; Baisanov, S.O.; Akhtanova, R.S.; Myshkin, O.N.; Kreimer, E.L.; Abdrakhmanov, A.K.; Sibgatullin, R.R. Reduction of iron from iron-carbon briquets in electrosmelting of steel. Steel Transl. 2007, 37, 702-705. [CrossRef]

17. Mizuno, K.; Kamiya, Y.; Yamada, T.; Inoue, M.; Soejima, H.; Enomoto, K.; Kaneko, T. Development of a new method of recycling stainless steel by products into EAF. SEAISI Q. 2007, 36, 66-72.

18. Elanskii, G.N.; Babich, V.K.; Smirnov, G.A.; Perevalov, N.N. Oxide-carbon briquettes are a reserve for steelmaking shops. Steel Transl. 2001, 31, 40-42. 
19. Echterhof, T.; Willms, T.; Preiß, S.; Omran, M.; Fabritius, T.; Mombelli, D.; Mapelli, C.; Steinlechner, S.; Unamuno, I.; Schüler, S.; et al. Developing a new process to agglomerate secondary raw material fines for recycling in the electric arc furnace-The Fines2EAF project. In Proceedings of the CLEAN TECH 4-The 4th European Conference on Clean Technologies in the Steel Industry, Bergamo, Italy, 28-29 November 2018.

20. Steele, R.B.; Bizhanov, A.P. Stiff Extrusion Agglomeration of Arc Furnace Dust and Ore Fines For Recovery at a Ferro Alloy Smelter; JC Steel and Sons Inc.: New Orleans, LA, USA, 2011; Volume 32, pp. 41-53.

21. Pietsch, W.B. Agglomeration Processes: Phenomena, Technologies, Equipment; John Wiley \& Sons: Hoboken, NJ, USA, 2002.

22. Echterhof, T.; Willms, T.; Preiss, S.; Aula, M.; Abdelrahim, A.; Fabritius, T.; Mombelli, D.; Mapelli, C.; Steinlechner, S.; Unamuno, I. Fabrication of Agglomerates from Secondary Raw Materials Reinforced with Paper Fibres by Stamp Pressing Process. Appl. Sci. 2019, 9, 3946. [CrossRef]

23. Lotfian, S.; Ahmed, H.; Samuelsson, C.; El-Geassy, A.A. Alternative Reducing Agents in Metallurgical Processes: Gasification of Shredder Residue Material. J. Sustain. Met. 2016, 3, 336-349. [CrossRef]

24. Wei, Z.; Zhang, J.; Qin, B.; Dong, Y.; Lu, Y.; Li, Y.; Hao, W.; Zhang, Y. Reduction kinetics of hematite ore fines with $\mathrm{H} 2$ in a rotary drum reactor. Powder Technol. 2018, 332, 18-26. [CrossRef]

25. Morandeau, A.; Thiery, M.; Dangla, P. Investigation of the carbonation mechanism of CH and C-S-H in terms of kinetics, microstructure changes and moisture properties. Cem. Concr. Res. 2014, 56, 153-170. [CrossRef]

26. El-Didamony, H. Application of differential thermogravimetry to the hydration of expansive cement pastes. Thermochim. Acta 1980, 35, 201-209. [CrossRef]

27. Drobíková, K.; Plachá, D.; Motyka, O.; Gabor, R.; Kutláková, K.M.; Vallová, S.; Seidlerová, J. Recycling of blast furnace sludge by briquetting with starch binder: Waste gas from thermal treatment utilizable as a fuel. Waste Manag. 2016, 48, 471-477. [CrossRef] [PubMed]

28. Kononov, R.; Ostrovski, O.; Ganguly, S. Carbothermal Solid State Reduction of Manganese Ores: 3. Phase Development. ISIJ Int. 2009, 49, 1115-1122. [CrossRef]

Publisher's Note: MDPI stays neutral with regard to jurisdictional claims in published maps and institutional affiliations.

(C) 2020 by the authors. Licensee MDPI, Basel, Switzerland. This article is an open access article distributed under the terms and conditions of the Creative Commons Attribution (CC BY) license (http://creativecommons.org/licenses/by/4.0/). 